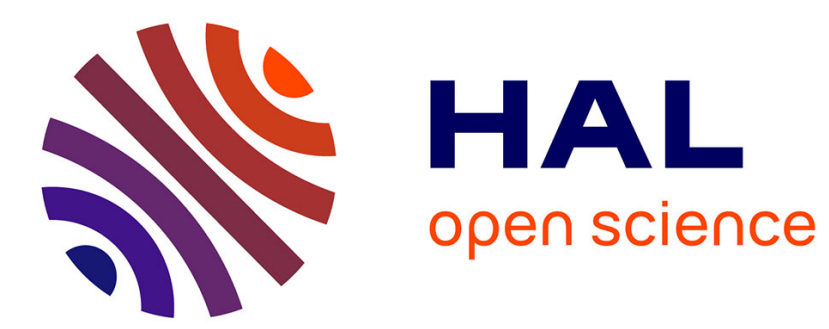

\title{
Science and innovation
}

Joelle Forest

\section{- To cite this version:}

Joelle Forest. Science and innovation. Journal of Innovation Economics \& Management, 2014, 2014(3)

(15), pp.196. 10.3917/jie.015.0003 . halshs-01064725

\section{HAL Id: halshs-01064725 \\ https://shs.hal.science/halshs-01064725}

Submitted on 17 Sep 2014

HAL is a multi-disciplinary open access archive for the deposit and dissemination of scientific research documents, whether they are published or not. The documents may come from teaching and research institutions in France or abroad, or from public or private research centers.
L'archive ouverte pluridisciplinaire HAL, est destinée au dépôt et à la diffusion de documents scientifiques de niveau recherche, publiés ou non, émanant des établissements d'enseignement et de recherche français ou étrangers, des laboratoires publics ou privés. 


\section{SCIENCE AND INNOVATION}

\section{Joelle FOREST}

University of Lyon, INSA Lyon

ITUS Research Team - Centre des Humanités, France

joelle.forest@.insa-lyon.fr

\section{Pour citer cet article}

Forest Joëlle, «General presentation », Journal of Innovation Economics \& Management 3/ 2014 (n`15), p. 3-9, www.cairn.info/revue-journal-of-innovation-economics-2014-3-page3.htm.

We live in a society in which technical objects are omnipresent; where technology transforms our world and conceives its future shape. However, we are faced with a paradox which becomes more and more pressing. Technique influences us and we remain largely unaware of it. If we fail to conceive technique, then it is because we do not know how to do it. We have not learnt to apply Logos, or thought, or, more generally, science with regards to technique. Theoretical reflections on technique, on technology, the integration of technique or technology into the boundaries of science, have not occurred as a matter of course.

Indeed, although archaic societies precluded invention, seeing technical objects as imitations of nature, Ancient Greek philosophy secularized technology, releasing it from the realm of magic and the divine to which it had been confined (Lamard, Lequin, 2006). In Aristotelian thought, the technical arts, which are a product of the metis, do not qualify as instruments of knowledge. The technical arts find themselves rejected from the Logos (Stiegler, 2004). They are not considered as an object of scientific knowledge. Consequently, in Metaphysics, Aristotle considers the technical arts to be intellectual activities with greater value than experience (a man of art knows the how and the why). Nevertheless, they have less value than science, hence making the technical arts a non-science. Finally, and as Sigaut (1994) pointed out, "technology is not what it should be because society does not yet consider the technical arts to be an interesting object of knowledge. And a science cannot exist if the object of that science is not legitimized by society".

By promoting works of the mind, the European Renaissance aroused renewed interest for technical art. During the Enlightenment, this interest was symbolized by the works such as Diderot and d'Alembert's Systematic Dictionary of the Sciences, Arts and Crafts (17511772):

"The mechanical arts which are dependent upon manual operation and are subjugated (if I may be permitted this term) to a sort of routine, have been left to those among men whom prejudices have placed in the lowest class. (...) However, the advantage that the liberal arts have over the mechanical arts, because of their demands upon the intellect and because of the difficulty of excelling in them, is sufficiently counterbalanced by the quite superior usefulness which the latter for the most part have for us. It is this very usefulness which reduced them perforce to purely mechanical operations in order to make them accessible to a larger number of men. But while justly respecting great geniuses for their enlightenment, society ought not to degrade the hands by which it is served. The discovery of the compass is no less 
advantageous to the human race than the explication of its properties would be to physical science. (...) However, it is perhaps in the artisan that one must seek the most admirable evidences of the sagacity, the patience, and the resources of the mind."

The Diderot and d'Alembert project opened the way for descriptive and classificatory technology. However, the word 'technology' did not become part of the common lexicon until Bigelow published his Elements of Technology in 1829. In his book, Bigelow supported a close relationship between science and technique in which science focuses on technical applications and in which techniques ("useful arts") feed on scientific advances. In such a paradigm, technique is a neutral, mechanical and transparent application of science and thus masked by that dominant science (Faucheux, Forest, 2012). Bigelow championed thus a conception of technology as an efficient process based on the application of science. This hypothesis founded the linear and hierarchical model of innovation.

From the beginning of the 1950s, the research and development (R\&D) was introduced into a first model called the linear model of innovation. In such a model, innovation is seen as an outcome of the science. It is no more than applied science. There is no innovation without research breakthrough. Researchers produce discoveries or new theories which will then be embodied in products by skilled engineers and exploited by opportunistic entrepreneurs (Forest, 2014). The innovation process is represented as a linear succession of stages. It goes from knowledge creation to technical application (development, production) and entrepreneurial practice (marketing).

The linear model of innovation helped to define the goals of innovation policies. For example, in France, during the 1960s, the research and development expenditures have tripled. $70 \%$ of the total of the research expenditures was then financed by the State. 1970s marked a slowing down. The French State decreased its effort while companies increased theirs. They rose from $29 \%$ in 1967 to $44 \%$ in 1979 . The 1980s saw the return of an increase in R\&D expenditures. They were multiplied by 3.7 between 1979 and 1991. The GERD passed from $1.8 \%$ to $2.4 \%$ (OST, 1998). In march 2000, such a model leads to the objective expressed within the framework of the Strategy of Lisbon to allocate 3\% of the European GDP in R\&D expenditures.

The gap between the statements of the linear model of innovation and monographies or statistical studies has indeed led theorists to propose a more complex view of the innovation process. There is no simple causal relation between the growth of scientific capacities (number of researchers, R\&D expenses...) or outcomes (number of articles...) and the rate of innovation (Bonnaure, Barré, 1995). In the mid 1980s, Kline and Rosenberg explained such a paradox by building what they called the "chain-linked model" (Kline, Rosenberg, 1986). Innovation involves several activities that should be closely associated by different loops. Moreover, Kline and Rosenberg underlined the key role of design. "The central process of innovation is not science but design" (Kline, Rosenberg, 1986).

In the 2000s, many studies have confirmed Kline and Rosenberg's insight. Indeed, a recent survey of Swedish companies shows a very interesting fact. Firms that use their design activity as a strategic driver are five times as likely to develop new products as compared to firms that do not (Swedish Industrial Design Foundation, 2008; European Commission, 2009). Moreover, these firms developed breakthrough innovations (Irish Center for Design Innovation, 2007; Tether, 2009). Moreover, data from Innobarometer 2007 show that more than $50 \%$ of innovative firms develop new products without performing R\&D. This statement 
has been confirmed by the European Community Innovation Survey (CIS, 2012), which underlines that almost half of innovative European firms did not perform in-house R\&D. Lastly, the OECD report (2010) reveals that the propensity to introduce a new product is similar whether or not the firm performs R\&D (Figure 1).

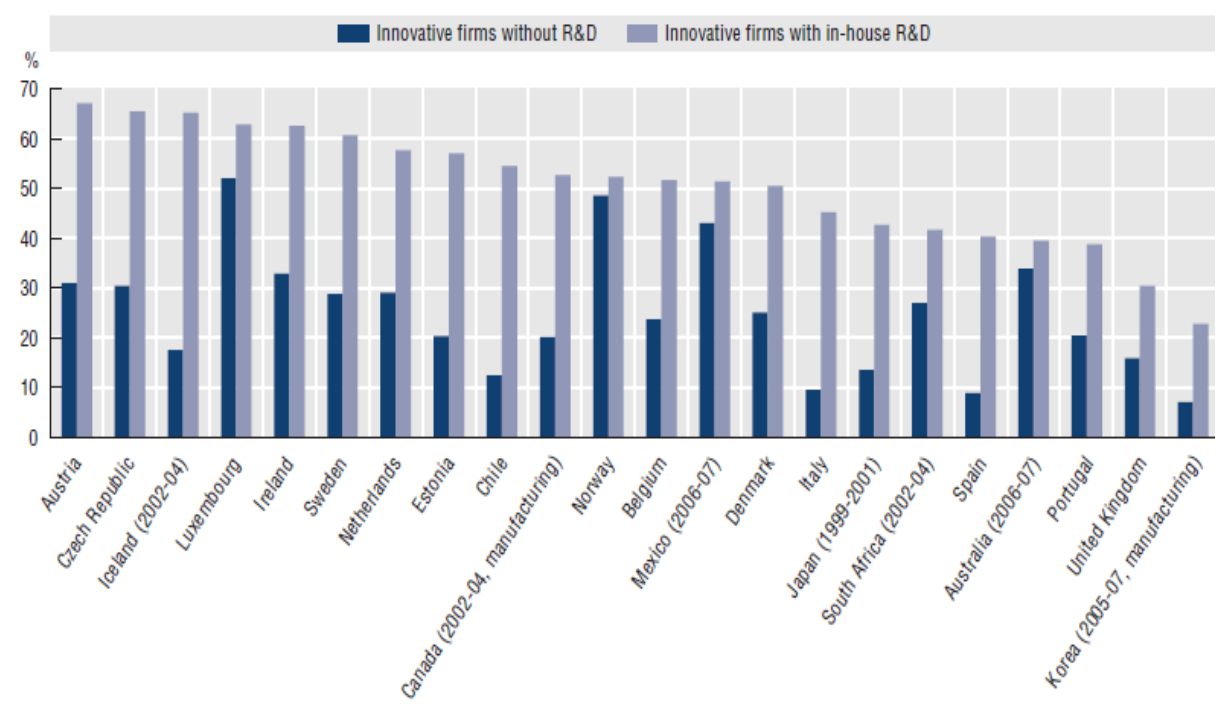

Figure 1 - Innovation beyond R\&D (OECD, 2010)

All statistical studies we mentioned lead us to conclude that non-R\&D innovation is a common phenomenon. If $R \& D$ seems to be an enabler of innovation, it is not sufficient by itself. Thus, the objective of this special issue is to question the relations between science and technology. What are the risks in continuing to use the linear model of innovation as the basis for policies to promote innovation? Is it not possible to go against the established paradigm of the application of sciences?

The first article of this special issue underlines that innovation conceived as a linear process is today the dominant point of view in the literature. However, Benoit Godin underlines that the very first sketch of such a model emerged much earlier, as a solution to a controversy in anthropology. Nineteenth-century discussions of changes in culture and of the role of different factors in culture change gave rise to a now-forgotten controversy among anthropologists. Godin shows that if "diffusion" as source of civilization was discussed among philosophers, some anthropologists began placing the emphasis on "invention". This soon gave rise to a controversy between advocates of invention and those of diffusion. According to Godin, the resolution of this controversy has remained influential in later studies of technological innovation from sociology to management and economics. It led to the study of innovation as a process over time, from invention to diffusion, thus strengthening a linear view of innovation. Yet, today the pendulum has swung back again: invention is said to play a minor role in innovation.

In his paper What does Innovation stand for? Review of a watchword in research policies, Bontemps states that innovation is not a well established concept. The notion permanently seems to oscillate between two meanings. The first one is restrictive. Innovation is a pure technological phenomenon. The second one is very wide. Innovation is an economic phenomenon, which gets closer to Schumpeter's conception. The word innovation also oscillates between its revolutionary dimension and its conservative character. Bontemps 
shows that innovation is on the agenda of all scientific policies without really being defined, which leads to inadequate research policies affecting researchers' work.

In their contribution How to improve Kline and Rosenberg's chain-linked model of innovation: building blocks and diagram-based languages, Jean-Pierre Micaëlli, Joëlle Forest, Éric Coatanea and Galina Medyna note that the linear model of innovation suffers from "oversimplification" (Rescher, 2013). Although an academic consensus exists about the value of Kline and Rosenberg's model, the authors propose that it can be improved to be more coherent with its systemic bases. The authors suggest conceiving an innovation system as an association of building blocks, and displaying this system by using different diagram-based languages. The proposed improved model enriches the set of viewpoints, entities and relations that can be used to depict an innovation system.

In the paper entitled New Insights Into Innovation: The Business Model Approach and Chesbrough's Seminal Contribution to Open Innovation, Katy Cabaret, Fabienne Picard and Nathalie Rodet-Kroichvili point out how the literature on business models conceptualizes the innovation process. Does the business model literature challenge the linear model of innovation? Does it contribute to a better understanding of current innovation processes? The paper highlights that the linear model of innovation supports a narrow conception of the innovation process. Moreover, it does not require any explicit reflection on business models. Then, the authors underline how the business model literature contributes to the renewal of the vision of innovation. It leads to a better understanding of the nature of science, technology, and their relationships with business. This literature insists on the core importance of the downstream stages, which reveal and exploit the economic value of technological opportunities, and to enlarge the possibilities for value creation and capture, including in the scientific sphere. In other words, without a reflection on the business model, technical innovations are likely to fail.

In A few arguments in favor of a holistic approach to innovation in economics and management, Manceau and Morand note that innovation is a misunderstood concept generating confusion. It is systematically associated with research and technology, moreover frequently according to a linear model, underestimating the various factors and the complex processes that drive it. Such a situation leads to public policies led by a misguided and partial view of innovation and a biased analysis of its drivers or enablers. Then the authors argue in favor of an enlarged view of innovation combining R\&D and creativity, and including recent trends such as design thinking, open innovation, digitalization, sustainable development and CSR, or resource-limited innovation.

The last article of this special issue puts in perspective the linear model of innovation with a case study. Merlin's contribution, Improving understanding of the innovation process in innovation-oriented public-private partnership, analyzes the complexity of the innovationoriented public-private partnerships (IPPPs) in the health sector. This case study illustrates the different levels of complexity encountered by the IPPPs, and the need to use an interactive but also dynamic framework to drive innovation (a new medical imaging machine). This case study leads the author to the conclusion that governments are no longer content to support the R\&D stage, but must implement measures which support innovation design process and network dynamics.

\section{REFERENCES}


ALEMBERT, (d') J. (1995), Preliminary Discourse, The Encyclopedia of Diderot \& d'Alembert. Translated by Richard N. Schwab and Walter E. Rex, Ann Arbor Publishing, University of Michigan Library, 2009. http://hdl.handle.net/2027/spo.did2222.0001.083, accessed January 15, 2014, Originally published as "Discourse Préliminaire," Encyclopédie ou Dictionnaire raisonné des sciences, des arts et des métiers, pp. 1:i-xlv (Paris, 1751).

BIGELOW, J. (1829), Elements of Technology, Boston, Hilliard, Gray \& Co.

BONNAURE, P., BARRE, R. (1995), Politique scientifique et technologique, Futuribles, $\mathrm{n}^{\circ} 204$, pp. 51-63.

BUNGE, M. (2004), Matérialisme et Humanisme : Pour surmonter la crise de la pensée, Montréal, PQ, Liber.

CIS (2012), Community Innovation Survey 2008-2010, Central Statistics Office, april 2012.

EUROPEAN COMMISSION (2009), Design as a driver of user-centred innovation, SEC(2009)501.

FAUCHEUX, M., FOREST J. (2012), Reflections on technology: A science of creative rationality?, in M. Faucheux, J. Forest (eds.), New elements of technology, Belfort, Pôle éditorial de l'UTBM, pp. 49-62.

FOREST, J. (2014), Petite histoire des modèles d'innovation, in Boutillier S., Gallaud D., Forest J., Laperche B., Tanguy C. and Temri L. (eds.), Principes d'économie de l'innovation, Bruxelles, Peter Lang, pp. 45-57.

HOLLANDERS, H., CRUYSEN, A. (2009), Design, creativity and innovation: a scoreboard approach. Pro Inno Europe

IRISH CENTER FOR DESIGN INNOVATION (2007), The design difference. A survey od design and innovation amongst Ireland's SME's.

KLINE, S., ROSENBERG, N. (1986), An overview of innovation, in R. Landau., N. Rosenberg (eds), The Positive Sum strategy, Washington, National Academy Press, pp. 275305.

LAMARD, P., LEQUIN, Y.C. (2006), La Technologie entre à l'Université : Compiègne, Troyes, Belfort-Montbéliard, Belfort, Pôle éditorial de l'UTBM.

OECD (2010), Measuring Innovation: A New Perspective, OECD, Paris based on OECD Innovation microdata project.

OST (1998), Les chiffres clés de la science et de la technologie, P. Mustar (dir.), Paris, Economica.

RESCHER, N. (2013), How Modeling Can Go Wrong: Some Cautions and Caveats on the Use of Models, Philosophy \& Technology, 26, 1, pp. 75-80.

SIGAUT, F., (1994), Les points de vue constitutifs d'une science des techniques : essai de tableau comparatif, in J. Perrin (ed.), Construire une science des techniques, collection technologie(s), Limonest, L'interdisciplinaire, pp. 381-397.

STIEGLER, B. (2004), Philosopher par accident, Paris, Galilée.

TETHER, B. (2009), Design in Innovation Coming out from the Shadow of R\&D An Analysis of the UK Innovation Survey of 2005, Department for Innovation, Universities and Skills Research Report 09-12, London.

UK DEPARTMENT OF TRADE AND INDUSTRY (2005), Creativity, design and business performance, Economics Paper, ${ }^{\circ} 15$. 